\title{
ESL Learners and the English Language Diphthongs: A Case of Major and Minor Languages in Nigeria
}

\author{
Olayinka M. Iyekekpolor* Josephine U. Akabogu \\ Department of Arts Education, University of Nigeria, Nsukka, Nigeria \\ *E-mail of the corresponding author: yinkaiyekekpolor@gmail.com
}

\begin{abstract}
The English language has come to stay in Nigeria; it is the language of education, commerce and unity, importantly, a global language. Learners of English as Second language (ESL) in Nigeria today go beyond the shores of the country in search for job opportunities and better livelihood. Inability to speak the English language intelligibly definitely will lead to frustration in the new environment and can hinder achievement of future goals in career step. The paper is an attempt at exploring dynamic ways of teaching the English language diphthong with the goal of awakening interest of students in the learning of speaking skill. The focus is on English language diphthongs with particular emphasis on the closing diphthongs. The paper has attempted to discuss the importance of speaking skill in the drive toward proficiency in the English language. The differences in the indigenous languages in Nigeria and the English language are explained. Influence of native speaker's language on the learning of English language is not left out of the discourse while the role of access to native speaker pronunciation is emphasised. Hopefully the identification of the discrepancies in the major and minor languages in Nigeria vis a vis the English language will stir up in the teachers in Nigerian schools to efficiently and effectively prepare students for life beyond the shores of Nigeria It is hoped that if English language teachers in Nigeria device new ways of teaching the oracy skill, learners will move towards competence in English language.
\end{abstract}

Keywords: English language diphthongs, indigenous languages, dialects, Mother Tongue (MT), Second language (SL), Second language learner, target language, Interference, Skills of English language, poor performance.

DOI: $10.7176 /$ JLLL/72-07

Publication date:October $31^{\text {st }} 2020$

\section{Introduction}

The English language commands a great pre-eminence in Nigeria when compared to indigenous languages in the country and other languages of the world. It is the official language of the country, the language of interethnic communication, medium of instruction in schools, language of both local and international trade. The importance attached to English language necessitates that, to function well at any level or capacity in the Nigerian society, an individual needs to be able to communicate well in English language. Proficiency in the four basic skills of the English language is essential if learners are to boast of competence in the language. The focus of this discourse is the speaking skill with particular focus on diphthongs of English language.

The English language is learnt as a second language (SL) in Nigeria. A second language is that language that is not native to the speaker; a language that is learned in addition to the language a person first learned as a young child. It is a language different from the mother tongue (MT) which an individual or the community uses. It is a non-native language that is officially recognized and adopted in a multilingual country (like Nigeria) as a means of public communication. The second language is any language that an individual uses apart from the first or native language ${ }^{15}$. Mother tongue (MT) is the language of an individual ethnic group. A language learnt as a baby or a language one has been exposed to from birth. The process of learning a second language differs from how the mother tongue is acquired. The mother tongue is acquired naturally, while the second language is learnt through artificial process ${ }^{3}$.

The ability to speak is peculiar to human beings; Speaking is an unavoidable act peculiar to humans ${ }^{16}$. Emphasis on the teaching of speaking skill therefore will help to build confidence in the learner of the English language as a second language. English language learners at the secondary school level communicate in speech; make use of the English language in the classroom and in the world outside the classroom. Opportunities arise at various times for students at this level to be involved in debates, cast news during assembly in schools, prefects (student' officials) give announcements to other students, communicate with teachers and parents. These occasions require the use of the English language through speech. 
Unfortunately, despite the frequent need to communicate in English language, learners find it difficult to pronounce certain words correctly. Learners of the English language as a second language are faced with the problem of oral proficiency. Poor intonation and misrepresentation of the English language sounds often characterize the speech of ESL learners. Learners of the English language have challenges with pronunciation ${ }^{10}$. Pronunciation is an aspect of language learning that is more difficult to master by a second language user especially after adolescence ${ }^{19}$ bearing in mind the proposition on the Critical Period Hypothesis (CPH). One major factor responsible for this is the problem of interference of the Mother Tongue (MT) of the learner which influences the ability to pronounce English language words. Second language learners have problem arising from prior pronunciation instruction and insufficient knowledge of English language speech sounds and the differences that exist between English language sounds and sounds of other languages ${ }^{10}$. The consequence of this defect is the exchange of sounds learners are familiar with in their Mother tongue to replace seemingly similar sounds in English language; thereby leading to poor pronunciation and consequently exhibition of poor speaking skill. Mother tongue interference continues to be the most obvious cause of difficulty learners of the English language face in Nigeria because mistakes made by learners in the English language are traced to the mother tongue ${ }^{1,16}$. It is quite natural to have mother tongue interference when people learn another language different from their mother tongue 3. Interference is applying knowledge from one language to another, particularly the knowledge of the first language of a learner to the second language or what can be regarded as the target language (the language being learnt by the learner other than the first language). This is technically referred to as inter-lingual (language) interferences. Inter-lingual interference is the negative transfer of the form and meaning of the native language of the learner to a second language. It features phonic interference which is a factor of the differences in the sound systems of the two languages - native language and English language ${ }^{17}$. It has been stressed that interference of the mother tongue and insufficient knowledge of sounds and the sound system of English language contribute to the problem faced by learners ${ }^{10}$ in ESL classroom. Effective learning of pronunciation therefore is of paramount importance in a classroom where it is taught as a second language.

Newly admitted undergraduate students were observed to be quiet and shy due to the fact that they had not been able to attain expected level of perfection of accuracy in the pronunciation of individual sounds of English language ${ }^{10}$. Lack of mastery of English language speaking skill, is capable of making students artificial autistic learners in an English language classroom. Confidence with pronunciation enables learners to be able to interact with native speakers of the English language and peers freely ${ }^{19}$. Secondary schools in Nigeria have not prepared students competently enough in English language ${ }^{6}$. This is evident in the students' incompetence in the Use of English course at their first year in the university. An attempt therefore at teaching the diphthongs of the English language at the Senior Secondary will facilitate improvement in the speaking skill of the English language learner before gaining admission to the university.

\section{The English language diphthongs}

A diphthong is a sound that is formed by the combination of two vowels in a single syllable. The sound begins as one vowel and moves towards another7 diphthongs can then be referred to as vowel glides. Glide is the most important feature of diphthongs9. In the course of articulation there is movement of the tongue smoothly between two positions. There are eight diphthongs in English language as represented by the Phonetic chart which are: /ei/, /ai/, / oi/, /au/, /ou/, /eə /, /ue/, /iə/. These can be classified into two groups which are centering diphthongs and closing diphthongs. Centering diphthongs end with a glide towards central vowel /a/ they are: /eə / as in there, /ue/ as in sure, /iə/ as in clear. Closing diphthongs are those which end with a glide towards $/ \mathrm{i} /$ or towards $/ \mathrm{u} /$. The glide is towards higher position in the mouth. Closing diphthongs are: /ei/; /ai/;/oi/; /au/; /ou/. /ei/ as in they; /ai/ as in mighty; /oi/ as in boy; /au/ as in now; /ou/ as in go.

In the course of articulation of English language diphthongs, there is movement of the tongue smoothly between two positions and the first vowel is expected to be longer and stronger than the second vowel this poses a challenge to non-native speakers of the English language as equal length is given to both vowel sounds as influenced by Hausa language to a native speaker of Hausa13,9. The fact that the tongue and the lip position changes significantly is responsible for problems encountered by the ESL learners. In the articulation of closing diphthongs, whose second vowel is /i/ or / $\mathrm{u} /$, the lip is from open to close and the tongue moves from low to high in the course of pronunciation. In the articulation of centering diphthongs whose second vowel is /a/, has the lip and the tongue retro flexing gradually to the central vowel. 


\section{Contrastive analysis of the English language phonemes and some major and minor Nigerian languages}

In English language, spelling cannot be used to predict the pronunciation of words. The letters that are used in written language are realized in different forms when it comes to speech. It has been observed that there is no consistency between the letters of the English language and its pronunciation2. Certain sounds that exist in the English language are not found in the three indigenous languages (Igbo, Hausa and Yoruba) or dialects of the Nigerian learner. The fact that the combination of the same vowel sounds in English language words yield different pronunciation is a factor responsible for confusion in the process of learning of the English language to the Second language (SL) learner. Words such as 'lead' /li:d/ ( to go in front), lead /led/ (a metal), bear /beə(I)/ (animal), bear / beə(I)/ (tolerate) are examples of such. There are words with singular vowel spelling, but in pronunciation two sounds are realized; examples are: 'wind /waind/ (to blow air/ a gust of air), dove /dəuv/,(a bird), dove /dəuv/ (past tense of dive), close /klouz/(opposite of far), close /kləuz/ (opposite of open) are some of the reasons for the complexity second language learner face in learning the speaking skill.

There is absence of diphthongs in Yoruba sound system and this is responsible for why Yoruba learners of the English language find it difficult to articulate the closing and centering diphthongs16. The Yoruba sound system has 12 vowel sounds made up of 7oral sounds and 5 nasal sounds with no diphthongs. On the other hand the English language sound system consists of 20 vowel sounds with 12 pure vowels and diphthongs. In the Yoruba language there is no combination of two vowel sounds within the same word. Combination such as :

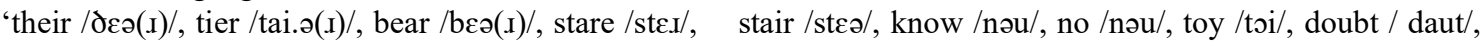
buoy /boi/, bye /bai/, buy /bai/, by /bai/, knight/nait/, night/nait/, wright/rait/, write/rait/, right/rait/, rite /rait/, brake /breik/, break/breik/, raise /reiz/, rays /reiz/ are not found. These differences result in the learner's attempts to pronounce English sounds as perceived by the ear in relation to similar sounds in local languages or dialects.

The Hausa language has 13 vowels, 10 pure vowels and 3 diphthongs which differ from that of the English language. The Hausa pure vowels are divided into two parts which are 5 short vowels and 5 long vowels. Hausa vowels appear in pairs; the long vowels are the equivalents of the short vowels. The Hausa diphthongs are /ai/; /au/ and /ui/ while the English language diphthongs are 8 in number as earlier stated. Only two diphthongs of the Hausa language are similar to the diphthongs of the English language; these are /ai/ and /au/. The english language diphthongs therefore poses problem to the native speakers of the Hausa language. learners produce pure vowels instead of diphthongs for instance the word 'gate' is produced as /get/ instead of /geit/. In English diphthongs are spelt differently e.g. /ai/ as in dine while in Hausa diphthongs are always spelt as they are pronounced /ai/ as in 'saida' (sell), /au/ as in 'farauta' (hunting). In Hausa language, diphthongs do not begin words, this is a possibility in English language with words such as 'isle', 'oil', 'owl' these words begin with /ai, oi , and au/ respectively. Disparity likewise exists between pure vowels of both languages. The pure vowels of the English language are spelt differently e. $g$ /i/ is spelt 'i' , 'a' , 'e' as in sit, private and wicked while the Hausa long and short vowels are spelt alike and differences in meaning of words arise only from pronunciation13. These differences result in the poor mastery of the English language particularly in reference to the speaking skill.

The Igbo language has 8 vowels which are: /i, e, u,o/ and / I, a, $\mho, \mathrm{s} /$; three of these vowels are represented with dot underneath $/ \mathrm{i}, \mathrm{o}, \mathrm{u} /$ these are different from the English language vowels. In the light of the various diversities that exist in the orthography of indigenous languages in Nigeria and the English language, non-native learners are bound to be influenced by their mother tongues in the learning of the English language.

In the study titled: phonological problems of Igala speakers of English language' one of the major causes of pronunciation errors is that Igala language poses a problem of pronouncing words as they are spelt17.; this is in opposition to what is obtainable in the English language. The diphthongs of the English language cannot be realised by the Igala speakers. They articulate diphthongs as a single vowel e.g words such as 'favour/feiva/ is pronounced as /fevọ/ and 'Roman /rəumən/ pronounced as /romæn/, sailor /seilə/ pronounced as /selọ/.

The study titled: 'mother tongue interference in the pronunciation of English among Ibibio students in Uyo urban: problems and prospects' reveals that most Ibibio native speakers have challenge with the following diphthongs of the English language- /əu/, /ei/ and /uə/ so that words such as 'go /g əu/, gate /geit/ and poor/puə/ ' are pronounced wrongly5.

Research has revealed that one of the greatest challenges facing speakers of English as a second language is the inability to pronounce most English sounds the English way19. Studies have revealed that secondary students in Uyo find it difficult to pronounce the diphthongs /iə/ and /uə/; /ei/ and /əu/19.

The study titled: 'A historical survey of Nigerian spoken English and its implications for outer circles Englishes' reveals that the several years of the existence of the spoken English in Nigeria has not made the versions of English language spoken in Nigeria to resemble the native-speaker's variety and may never assume the 
posture20. This is like giving up on efforts at attaining competence in the learning of the English language. Nigerian speakers of English often articulate diphthongs /iə/ as /ia/ or as /ie/; /eə/ is realised as /e/; /uə/ as /ua/. The study established the fact that the spoken English in Nigeria differs from the standard British English.

The diphthong of the English language which is the focus of this practicum is part of the English language sounds tested at the Senior Secondary Certificate Examination Level (SSCE) / WAEC. Emphasis on proficiency in spoken English was introduced into the National Curriculum in 1980s1 and was added to the English language West African Examination Council (WAEC) paper in 198811. The speaking skill was taught as oral English initially at the secondary schools. Students' oral skill was tested in form of listening comprehension test accompanied with multiple choice objective questions. The items of the objective tests were designed to test if the learner could recognize consonants and vowel sounds, stress, intonation, understand dialogues and narratives. Oral skill test then involved the use of tape recorders and compact disc players. This approach to the teaching and testing or speaking skill though laudable, was faced with lots of challenges. There were no language laboratories in schools, for the recording of reading materials. There was dearth of qualified examiners as variations in the spoken English of the examiners resultantly led to variation in scores awarded to candidates. There was increase in the number of enrolment of students into secondary schools which also led to the increase in the number of English language candidates because all students offer the subject. Lack of competent and qualified teachers, lack of instructional materials and conducive environment have been identified as part of the factors militating against the effective teaching of the spoken aspect of the English language4.

The challenges associated with the examination of the speaking skill of the English language, gave rise to the adoption of the use of orthographies to replace spoken words through the aid of the International Phonetic Alphabets (IPA). The IPA is used by phoneticians for the purpose of transcription by using symbols to represent sounds. The WAEC English language paper which all senior secondary students must face at the end of their six year course in the secondary school is designed to test the candidate's knowledge of English language sounds and it is a compulsory paper in the testing and certification of the English language at this level. Questions are set to reveal if students can recognise meaning, tones and attitude and use of acceptable pronunciation through stress mark placement21. The aforementioned have revealed that, the languages in Nigeria do not feature most of the diphthongs of the English language. This is the reason therefore for the teaching of the English language diphthongs.

\section{Theoretical basis for the teaching of English language diphthongs in an ESL environment}

Behaviourist theory by B.F. Skinner (1904-1990) postulates that learning is a result of habit formation. Language acquisition is a matter of forming and performing habits ${ }^{18}$. The implication of this fact is that to learn a language there is the need to practice the use until it becomes a habit. In order to avoid mistakes in pronunciation and spelling of English language diphthongs, students need a lot of training ${ }^{8}$ in line with the view of behaviourist that posits that the role of imitation and repetition is very vital in language learning ${ }^{18}$. In the teaching of the English language in this practicum, it is important to teach English language diphthongs with the corresponding letters that make up the sound. Computers or specialised videos will be of immense help in the articulation of English language diphthongs in line with the fact that the behaviourist theory presents language as a conditioned behaviour ${ }^{8}$. Leaners should have the opportunity to listen to native speaker's pronunciation pattern as model and be given the space to imitate what is perceived by their ears. The use of the 'wheel of phoneme' and wheel of diphthong' (adapted and designed by one of the authors) can give room for the practice of articulation of the English language diphthongs so that learners are involved in activities as the lesson lasts. These are to aid the creation of positive language learning environment as behaviourists posit that language learning is influenced by learners' environment ${ }^{18}$. Learners are expected to make use of the knowledge acquired to express themselves in sentences reflecting activities in the classroom and day to day life. The deliberate efforts at the teaching of English language diphthongs possibly will develop near native speaking skill in the ESL learners at the secondary school level.

\section{The Use of Multisensory Approach in the Teaching of the English language Diphthongs in ESL Classroom}

An approach is a theoretical way of viewing teaching and learning which encompasses a set of ideology, belief or logical assumption that could facilitate better understanding of issues. An approach is general and it gives rise to methods which it is the practical realisation of an approach. Method can also be defined as a group of procedures or systems that is clearly explanatory. A target plan or set of orderly procedures that are based on an approach. Methods carefully reveal what is to be done in a systematic way. Method has to do with how a teaching activity is carried out in order to achieve the objectives of teaching. 
Multisensory approach means presenting all information to learners through appeal to more than one of the senses of the body at a time. It is an approach that involves two or more of the senses within the same learning activity. Different learners learn in a variety of ways. Multisensory learning approach helps the learner to discover the best way he/she can learn and that best fits the objective of learning. It is an approach that involves all the parts of the brain in the course of learning. Students are made to learn through seeing, hearing and touching. In order to appeal to the sense of seeing which is visual, pictures, images, real life, printed books, flash cards with identifying pictures, shapes and other visual aids are involved. The sense of hearing is arrested through recorded voices, discussions, questioning, dialogue, audio books and the sense of touch is utilised for teaching through the involvement of years that multisensory approach is valuable in language learning ${ }^{12}$. The 'Wheel of phoneme', 'Wheel of diphthongs', 'phoneme cards' (adapted and designed by the author) and you-tube video of native speakers are the multisensory materials that can facilitate the teaching of English language diphthongs.

Display of English language words containing diphthongs in the different positions of the word which from phonetic point of view does not exist in the indigenous languages of the second language learner in the classroom; in order to aid learning of the target language and also provide words of the English language that feature diphthongs similar to the ones available in the indigenous languages as well ${ }^{8}$ can go a length to help the ESL learner.

Behavioural modelling method is a way of teaching that involves the presentation of ideal behaviour ${ }^{14}$. Learners can be exposed to the ideal pronunciation of the English language diphthongs through the use of downloaded video from the You Tube this probably may aid the students to articulate the diphthongs correctly. The sounds as uttered by native speaker is crucial to the success of the pronunciation lesson because researches have revealed that many non-native English language teachers have their spoken English influenced by various forms of inflections which tend to corrupt the near native articulation of the English language diphthongs.

\section{Recommendations}

In the light of the discourse above, the following recommendations were made.

1. English language teacher training programme should intensify efforts on mastery of the English language sounds

2. Teachers of English language need to place premium on the teaching of English language sounds with particular focus on the diphthongs

3. Teacher training curriculum for English language teachers should incorporate the use of computer technology

4. More time should be carved out on the school time-table for the teaching and learning of English language

5. The teaching of test of orals should be regularly carried out on weekly basis

6. Facilities should be made available in schools for the practical demonstration of the theoretical aspect of speaking skill

7. English language teachers should be motivated through special pay package or remuneration as motivation to encourage further commitment to the teaching and learning of the subject.

\section{Conclusion}

The teaching of speaking skill of the English language is necessary in order that students who graduate from the secondary schools can display a reasonable level of mastery of the English language and be fit for life outside the shores of Nigeria. Teachers at this level therefore need to ensure that the teaching of oral English moves from teacher centred approach to activity based. Students need to participate in the learning process so as to make discoveries and internalise the correct articulation of the English language diphthongs and on a broad basis, the English language sounds.

\section{References}

1. Adeolu, O. (2018). Factors affecting secondary school oral English. Retrieved from www.academis.edu. on $25 / 2 / 18$.

2. Aina, M. O. (2015). Linguistic problems of Nigerian learners of spoken English. Journal of qualitative education 11(1) 1-7.

3. Bishara, M. (2015). Mother tongue interference: A contrastive analysis of English and Malayalam 
diphthongs. International Journal of interdisciplinary and multidisplinary studies (IJIMS0 2(5) 102-105. Retrieved online from http://www.ijims.com on 9/6/18.

4. Chuta, S.C. (2016). Why students fail English. A publication of The Sun newspaper of 5th April, 2016.

5. Edem, E. (2015), Mother tongue interference in the pronunciation of English among Ibibio students in Uyo Urban: Problems and prospects. Multidisciplinary Journal of Academic Excellence, Vol.12, 12(1) 1-14 Retrieved from www.globalacademicgroup.com>journals on 9/6/2018.

6. Edem,E. (2016), Background influence on the use of English among first year students of Akwa Ibom state university, Akwa-Ibom State. Journal of Assertiveness, Vol 11(1).1-9.

7. English Oxford Dictionaries (2018). Definition of diphthongs. Oxford University Press. Retrieved online from https://en.oxforddictionaries.com on 8/6/2018.

8. Fuciji, M. B. \& Babârâ, E. D. (2011). Mother tongue interference in the process of English diphthongs' study. Retrieved from philology.knu.ua>Studia_Linguistica_5_522_529 9/6/18.

9. Huang, Q. (2016). Experimental research on English vowel errors analysis. Retrieved from https:www.shsconferences.org?2016/03 pp 1-5 DOI: 10.105511/shsconf/20162501002 9/6/18.

10. Iyere, T. (2013). Pronunciation challenges of open and distance learning students in the B.A English programme at the National Open University of Nigeria. International Journal of English and literature. 4(5) 217-222. DOI: 105897/IJEL2013.0456. Retrieved online from http://www.academicjournal.org/IJEL on $\underline{9 / 6 / 18}$.

11. Iyorza, S. (2018). Audio-visual media education and oral English teaching in Nigerian schools. Retrieved from www.academia.edu>oral English on 25/2/18.

12. Maheshwari,V. K. (2016), Multi-sensory teaching- Meaning and importance. Retrieved from www.vkmaheshwari.com on 11/6/2018.

13. Malah, Z. \& Rashid, S. Md. (2015). Contrastive analysis of the segmental phonemes of English and Hausa languages. International Journal of languages, literature and linguistics. 1(2) 106-112.

14. Nadezhda, O.Y \& Evgeny, V. (2014). Interactive teaching methods in contemporary higher education. Journal of pacific science review. 16(2) 75-80. Retrieved from https://www.science direct.com/science/article/pii/S1229545014000175 on 22/2/18.

15. Nordquist, R. (2017).What is second language (L2)? Definition and examples. Retrieved from https://www.thoughtco.com>second-lan... on 10/6/2018.

16. Ogundepo, A. O. (2015), Contrastive study of English and Yoruba morphological systems- implications for Nigerian teachers and learners of English. International Journal of English language and linguistics research. Vol 3,(4), pp.1-8.Retrieved from www.eajournal.org.

17. Olorunsogo, D; Daniel, O; Oluwayomi, S; Abiona, R \& Godwin, F. (2017). Phonological problems of Igala speakers of English language. Retrieved from https://davidolorunsogo. wordpress.com/2017/07/01/phonological-pr.

18. Oyetunde, T.O. (2013). The intentional English teacher: theories, methods \& activities. Tips for teaching English functionally. LECAPS, Jos.

19. Senam,N. \& Senam, K. (2017). English vowel pronunciation and its implication for speech communication among secondary school students in Uyo Nigeria. International Journal of English and Communication Studies. Vol 3 (3) 27-41 Retrieved from www.iiardpub.org. on 9/6/18.

20. Ubong, E.J. \& Nkereke, M.E. (2012). A historical survey of Nigerian spoken English and its implications for outer circles Englishes. Retrieved from https://www/researchgate.net/publication/286584492 on 9/6/18.

21. WAEC (2013). West African Examination Council, Marking Scheme. A publication of WAEC, Yaba, Lagos, Nigeria. 